\title{
КУЛЬТУРНО-НАЦІОНАЛЬНІ КОНОТАЦІЇ УКРАЇНСЬКИХ ФРАЗЕОЛОГІЗМІВ ІЗ АНТРОПОНІМІЙНИМ КОМПОНЕНТОМ
}

Юрченко Т. Г. Культурно-національні конотації українських фразеологізмів із антропонімійним компонентом.

У статті аналізуються антропоніми, що входять до складу українських ідіом. Деякі 3 них зберігають зв'язок із конкретними історичними постатями, а інші виступають як узагальнювальні назви-характеристики соціальних і морально-етичних пріоритетів українців.

Ключові слова: ідіома, фразеологізм, антропонім.

Юрченко Т. Г. Культурно-национальные коннотации украинских фразеологизмов с антропонимическим компонентом.

В статье анализируются антропонимы, входящие в состав украинских идиом. Некоторые из них сохраняют связь с конкретными историческими личностями, а другие выступают как обобщающие названия-характеристики социальных и моральноэтических приоритетов украинцев.

Ключевые слова: идиома, фразеологизм, антропоним.

Jurchenko T. G. Antroponyms forming part of Ukrainian idioms.

Antroponyms forming part of Ukrainian idioms are analysed in this article. Some of them sustain connection with specific historic personalities, others take the part of generalized names-testimonials of social, moral and priorities of the Ukrainians.

Key words: idiom, phraseological unit, anthroponym.

У лінгвістичній науці на сьогодні побутує слушна думка, що в ідіоматичності фразеологізмів яскраво втілюється національний колорит кожної мови. Як стверджує С. В. Семчинський, «ідіоми якраз i створюються не для опису світу і навколишньої дійсності, а для іiі інтерпретації, для вираження суб'єктивного, i, як правило, самостійно забарвленого ставлення мовця до світу, до дійсності» [6, с. 194 ]. Для ідіом, як відомо, характерна семантична синкретичність або концептуальна дифузність («донаукові» концепти, міфологічне тлумачення дійсності, нерозчленованість навколишньої дійсності). Наукові розвідки в цій царині завжди спираються на благодатне підгрунтя, адже «фразеологія надзвичайно мобільна мовна система, в ній часто стикаються і досить щільно переплітаються зусилля й наслідки різнорідної (в хронологічному, регіональному та інтелектуальному відношеннях) мовотворчості $[7$, c. 110].

Слідом за Л. А. Булаховським, виділяємо ідіоми в генетичному аспекті (за джерелами походження), розрізняючи передусім прислів'я i приказки [1]. На нашу думку, українська народна фразеологія належить до вершинного вияву національного фольклорного мистецтва. Якнайкраще самі про себе говорять прислів'я і приказки: Приказка - квітка, прислів'я - 
ягідка; Приказку і на кривій не об'їдеш; Приказка циганським (заднім) розумом живе; На приказку ні суду, ні розправи; Приказка неосудна; Із приказки слова не викинеш; Не всяке слово - приказка; Приказка плодюча $i$ живуча.

На сучасному етапі наукового пізнання потребує перегляду й традиція використання ідіом, до складу яких ввходять антропоніми, адже науці відомі фразеологізми з не лише українськими власними іменами, серед них i ті, корені яких сягають далеко за межі України (Ахіл, Венера, Прокруст тощо), також не описані випадки вживання сучасних українських розповсюджених імен в українських фразеологізмах. Роль імен в українських фразеологізмах стала об'єктом дослідження лінгвістів на різних мовних рівнях. Так, мовознавці В. Іванов, О. Афанасьєв, Б. Рибаков досліджували зв'язок української фразеології з іменами історичних осіб від часів Київської Русі. Важливою працею в цій галузі наукових розвідок $є$ «Галицько-руські приповідки» І. Я.Франка, надруковані у Львові в трьох томах: т. I, вип. 1 - 1901 р.; т. I, вип. 2 - 1905 р.; т. II - 1908 р. і т. III - 1910 p. Ця праця містить багато прислів”їв, приказок, крилатих виразів i народних ідіоматичних зворотів, зібраних автором на території Західної України. «Історичні» фразеологізми найколоритніше репрезентують ті 3 них, де згадуються конкретні історичні особи, чим, власне, ці вислови і цінні як фактичне джерело.

Актуальність нашого дослідження зумовлена тим, що вивчення фразеологічної мотивації охоплює цілий комплекс взаємопов'язаних теоретичних питань різних галузей науки: семіотики, когнітології, етнолінгвістики, антропології тощо. Метою дослідження $\epsilon$ аналіз особливостей фразеологічного семіозу - часткової інтерпретації інформації, закодованої у фразеологічній одиниці 3 антропонімійним компонентом. Поставлена мета передбачає розв'язання таких завдань:

1) визначити семантичний та експресивний потенціал ідіом, у складі яких є власні імена історичних осіб;

2) дослідити семантику фразеологізмів соціально-побутового спрямування.

Як відомо, появу власного імені зумовлювала необхідність виокремити когось чи щось із ряду подібних осіб чи предметів. Із часом індивідуалізовані власні імена перетворювалися на називні, тобто на узагальнені назви, i, позначаючи певне явище, певну рису вдачі людини, ставали засобом типізації. Отже, багато власних імен із повсякденного вжитку переходили, органічно вкраплювалися в живу фольклорну стихію, стаючи лексичною окрасою народних афоризмів.

Козацькі часи, насичені героїчними подіями, очевидці намагалися влучно і дотепно осмислювати. Особливою прихильністю і повагою пройняті фрази, присвячені Богданові Хмельницькому, завдяки якому український народ відчув себе творцем власної історії: Висипався Хміль із 
міха та показав ляхам лиха; За старого Хмеля людей була жменя тощо. Стосовно іншої талановитої, але суперечливої постаті - Івана Мазепи народна мудрість зафіксувала не зовсім однозначні судження. В окремих ідіомах схвалювався державний розмах діяльності опального гетьмана (Bid Богдана до Івана не було гетьмана), в інших - звучало відверте співчуття (Служив Москві, Іване, а вона його гане).

Поодинокі прислів'я, маючи конкретне історичне підгрунтя, згодом втрачали 3 ним зв'язок і зрештою набували самостійного значення, наприклад: Настя носить булаву, а Іван плахту. Кожний здогадається, що тут ідеться про чоловіка, який усі свої клопоти перекладає на жіночі плечі. А прислів'я це взяте з реального життя і стосується реальних людей. У ньому йшлося не про повсякденні турботи простого чоловіка, а про «труди i дні» державного мужа - гетьмана Івана Скоропадського та його честолюбної дружини Насті. Такі ідіоми кваліфікуємо як «історичні», тому що завдяки названим у них іменам можна «прочитати» сторінки 3 нашого минулого. Цих фразеологізмів народна скарбниця, на жаль, зберегла небагато. Проте народна мудрість витворила безліч «іменних» прислів 'їв, приказок так званого соціально-побутового характеру, які відобразили реальну картину соціальних, морально-етичних взаємин в українському суспільстві, переважно «природному» селянському середовищі.

Нині поширені прислів'я, приказки, загадки, де вживання власного імені мотивується тільки особливостями його інтонації, своєрідністю звукового складу та римованістю, що аж ніяк не применшує естетичної суті фразеологізму, а навпаки - наближає його до віршового жанру. Передусім українська й зарубіжна література збагачувала такими висловлюваннями мову. Слід відзначити також, що власні імена у складі ідіом мають різноманітне смислове навантаження. «Історичні» ідіоми найбільш колоритно репрезентують ті 3 них, де згадуються конкретні історичні особи, чим, власне, ці вислови і цінні як фактичне джерело. Загальновідомо, що від часів Київської Русі нам дісталося у спадок кілька таких висловів. Їх можна знайти майже в кожному лексикографічному джерелі. Наприклад: Зле, Романе, робиш, що литвином ореш (ідеться про князя Романа Ростиславовича, який, перемігши литвинів - так називали $\mathrm{i}$ білорусів, - став їх впрягати до плуга і таким способом «освоював» нові місця). Існує приказка й про іншого князя, добрішого: Князь Борис все плуги кував та людям давав [3, с. 45].

Надзвичайно плідно народна уява попрацювала над фразеологізмами соціально-побутового спрямування, вклавши в них самобутнє розуміння народної моралі, мудрості. Ім'я в цих ідіомах ставало засобом типізації, вказувало на широко розповсюджені явища, певні риси характеру людини тощо. У процесі творення фразеологізмів відбувалася послідовна, закономірна класифікація імен, яка $з$ часом усталилася. Деяким із них відводилася нейтральна роль, деяким - позитивна, а от окремим іменам 
катастрофічно не пощастило. На них покладалася функція означеньхарактеристик недотеп, брехунів і дурнів. Це, зокрема, Охрім, Химка, Хведько, Хівря, Хвеська, Гапка. Роль провідної української баляндрасниці посіла Хвеська. Язиката Хвеська - це вже вичерпне означення, що не потребує коментарів. Цей образ існує і в інших колоритних варіантах (Леська та Хвеська хоч якого дзвона перегудуть). Названі імена асоціюються також із образом людини неотесаної, некультурної, невдахи: На бідного Хому і дерево пада, На безлюдді і Хома чоловік, I ми, Химко, люди, Розумний, як Хведькова кобила. Та навіть саме ім'я Хівря чи Химка викликає в уяві специфічний образ людини.

Із відомих причин в українському середовищі традиційно переважали «селянські» імена. До них належить ім'я Іван, яке особливо прижилося на українському грунті, хоч воно за походженням давньоєврейське (Іоханан «дар Божий»). Найтрадиційнішим є народне сприйняття Івана як бідного, незаможного чоловіка, що відбилося й у прислів'ях: Не перший раз Іван бідний, Пан з паном, а Іван з Іваном, Що вільно панові, то не вільно Іванові. Водночас існує думка про Івана як про хитрого, спритного хлопця (цю рису характеру Іванів блискуче відтворив у своїх славетних гуморесках С. Руданський: «Іван і пан»). Російська фольклорна спадщина зафіксувала свій традиційний образ Івана - Іванушки-дурачка, на перший погляд, не дуже розумного, а насправді хитрого і кмітливого. Український фольклор теж має сюжети про не дуже розумного Івана. $Є$ анекдоти про двох розумних братів і третього - Івана. Однозначні і такі прислів'я: Ростом з Івана, а розумом в болвана, Мудрий Іван по шкоді: коні вкрали, тоді він стайню зачинив.

Прикметно, що в переважній більшості українські фразеологізми залучають імена випадково. Такий принцип уведення власних імен до складу фразеологічних одиниць можна назвати «принципом навмання». Головна умова - звичайність, поширеність, «простонародність» імені. У багатьох каламбурних прислів'ях ми зустрічаємося саме 3 таким способом залучення імен до висловлювань: Химині кури, Мотрині яйия, I мох, $i$ трава, $i$ Мелашка крива. Українське народне мовлення щедро «пересипане» i різнобарвними приказками, які за ритмомелодикою нагадують дитячі «дражнили». Кожна дитина намагається «причепити» до імені якусь лексичну всячину. У такий нехитромудрий спосіб твориться безліч прикладок. В основі їх - принцип римованості, добір імен за римою: 3 нашого Захарка ні Богу свічка, ні чортові угарка, Не вмер Данило, так болячка задавила. Поширеними були і «чисті» дражнилки: Герасим по кобилі голосив, Пилип до стіни прилип. У подібних «дражнилках» найчастіше мовець звертається безпосередньо до когось: Заплач, Матвійку, дам копійку, зареви - дам аж три, Микито, чи ти то?, Юрку, спечи курку. Цим видом народної творчості захоплюються діти дошкільного та молодшого шкільного віку, тому кожне сучасне ім'я 
завдяки їхнім зусиллям оздоблюється подібним, інколи не дуже милозвучним, але обов'язковим означенням-прикладкою.

Центральною фігурою в ідіоматичних виразах завжди виступає людина у всіх своїх розмаїтих проявах - від найвищих, найкращих своїх якостей до негідних. Прислів'я i приказки не лише узагальнюють багатовіковий життєвий досвід народу, а й містять емоційно-експресивну оцінку вчинків людини, подій, явищ. Наприклад: 1) стійкість, упертість: Неначе Іван-Покиван; 2) байдужість або небажання мати стосунок до чогось: Про мене ц̌ Семене; 3) лінощі, небажання працювати: Грицю, Грицю, до роботи! - В Гриця порвані чоботи! - Грицю, Грицюю, до Марусі! - Зараз, зараз приберуся!; Збирається, як Маланка на весілля; 4) егоїзм: У кожного Павла правда своя; 5) боягузтво: Думки Наполеона, а душа заяча; 6) набридливість: Як Маланка з ящиком; 7) образливість: Наш Федул губи надув; 8) гарна зовнішність: Ой лихо, не Петрусь, личко біле, чорний вус; 9) скупість: Багатий, як Крез, а живе, як пес (Крез - останній цар Лідії (595 - 546 р. до н. е.), що славився надмірним багатством); 10) безвір'я: Хома невіруючии; 11) довірливі люди, жертви обману: Не прогав, Хомо, на те і ярмарка; Дурний ти, Хомо, чоловік; Взули, як Пилипа в постоли; 12) Хитрий проти хитрого: Знаємо изього Хоку $i$ спереду, $i$ збоку; 13) злодійство: Каїнове сім'я; 14) нахабство: У Пилипа пили, Пилипа й побили; 15) сором: Який Сава, така й слава; 16) багатство і слава: Гроші $\epsilon$ - Іван Петрович, грошей нема - погана сволоч (наволоч); 17) про несхожість людей: $У$ всякого Мирона свої прийоми; 18) марна справа: Носиться, як Маланка з ящчиком; Дорвався, як Мартин до мила; Спохопився Данило, коли дочка народила; 19) голод, нестатки: Ніби Мамай війною пройшов; 20) тяжкі дні: Напали на Настю суцільні нещзастя; 21) смерть: Помер Мартин - то й грецьь із ним; 22) алкоголізм: Почав Омелько пити потихеньку; У нашого Купріяна всі діти п'яні; У Микити все пропите, аж дістався до корита; Сьогодні - Сави, завтра - Варвари, а підійшов Микола - і сідниці голі (цуе три свята, які йдуть одне за одним); 23) повчання крадіям, покарання: Видеруть тебе, як Сидорову козу; 24) безвідповідальність: Іван киває на Петра; 25) місце людини в суспільстві: На безриб $\dddot{\imath}$ i рак - риба, на безлюдді і Хома-чоловік; Краще бути на селі Богданом, ніж у місті Селиваном; 26) жити своїм розумом: Всякий Сремія про себе розуміє (пов'язано зі святом на честь пророка Ієремії (Среміï), таких свят на рік було сім, і вони звичайно збігалися 3 початком якихось польових робіт - Т. Ю.); 27) дурість: Піп хрестив Іваном, а прозвали бовваном; 28) про дівчину, жінку: Гарна наречена Ганнуся: хвалять мати й бабуся; Який Іванко, така у нього і Маланка; Я за свого Кузьму кого хочу, того візьму, а ти свою Яринку поводи по ринку; 29) про подарунки: Дороге яєчко на Христовий день тощо.

Як видно з наведених вище прикладів, у крилатих висловах народ типізував, узагальнював сюжети. I нині такі узагальнення актуальні, якщо приміряти їх 
до розмаїття життєвих ситуацій. На нашу думку, живе мовлення має повернути ïx у словниковий обіг. Це сприятиме збагаченню, урізноманітненню нашої спрощеної прагматичним часом мови, а багатобарвне розмовне мовлення додатково збагатиться трохи забутими, але експресивно переконливими, вивіреними мовною практикою довгожителями-фразеологізмами. Глибоке дослідження антропонімійного складу ідіом, їх значення в сучасній літературній мові допоможе збагатити не лише тезаурус носіїв української мови, а й їх світогляд стосовно історії, культури та естетичних уподобань свого народу.

\section{Література}

1. Булаховський Л. А. Нариси з загального мовознавства. Серія друга [Текст] / Л. А. Булаховський // Вибрані праці в п'яти томах. - Т. 1. - К. : Наук. думка, 1975. - C. 51-52.

2. Буслаев Ф. И. Русские пословицы и поговорки, собранные и объясненные [Текст] / Ф. И. Буслаев - М. : Изд-во АН СССР, 1954. - 537 с.

3. Герасимчук В. Власні імена в українських фразеологізмах [Текст] / В. Герасимчук // Дивослово. - 2005. - № 4. - С. 43-47.

4. Де живе жар-птиця? // Збірник українських народних казок, легенд, скоромовок, прислів 'їв, народних порівнянь [Текст]. - К. : Веселка, 1991. - 206 с.

5. Зимин В. И. Пословицы и поговорки русского народа. Большой объяснительный словарь / В. И. Зимин, А. С. Сирин. - [3-е изд., стереотип.]. Ростов-на-Дону: Феникс, Москва : Цитадель-трейд, 2006. - 544 с. - (Словари).

6. Семчинський С. В. Загальне мовознавство. Видання друге, перероблене i доповнене / С. В. Семчинський. - К. : АТ ОКО, 1996. - 416 с.

7. Ужченко В. Д., Авксентьєв Л. І. Українська фразеологія / В. Д. Ужченко, Л. І. Авксентьєв. - Х. : Основа, 1990. - 167 с.

8. Чабаненко В. А. Стилістика експресивних засобів української мови: Монографія / В. А. Чабаненко. - Запоріжжя : ЗДУ, 2002. - 351 с.

Стаття надійшла до редакиії 15.09.2010 p. 